\title{
Nature, Freedom and Gender in Schelling
}

\author{
Alison Stone
}

\section{Introduction}

In this essay I re-examine Schelling's ideas about nature and freedom from a feminist perspective. I look at first Schelling's First Outline of a System of the Philosophy of Nature, written in 1799-1800, i.e. during his 'early' period, then his Philosophical Investigations on the Essence of Human Freedom, from 1809, i.e. the beginning of his 'middle' period. These works differ in philosophical orientation, but there are significant continuities between them, including in their assumptions about gender. In both works, Schelling argues that two opposed yet interdependent metaphysical powers are necessary to the constitution of the world, and he interprets these powers in terms of a gendered polarity. Earlier, the polarity is between the natural force of male productivity and that of female inhibition. In the more theological framework of the Freiheitsschrift, the polarity is between the primordial, female generative power that is God's ground and the rational, male creative power that is God's existence.

Feminists have explored how assumptions about gender-about what it means to be male or female, a man or a woman - have figured into the history of European philosophy. Influential feminist scholars have identified sets of hierarchical oppositions running through this tradition - mind versus body, reason versus passion, free will versus natural determination. Within these oppositions, the most highly valued poles — mind, reason, freedom - have tended to be construed as 'male' and the inferior poles as 'female' (see, e.g., Lloyd 1984). For instance, women have repeatedly been seen as being at the mercy of their bodies and bodily impulses and so unable to rise to higher levels of intellectual or spiritual achievement—all this partly because the body itself has regularly been interpreted or 
symbolised $a s$ 'female'. These interpretations are not merely contingent and accidental, such that we could retain (say) the concept of the body but deny that the body has any female connotations. Rather, gendered interpretations have fed into the inherited meanings of many concepts - into our conceptions, if not necessarily our concept, of the body. Inherited conceptions can be re-thought and re-imagined, but this requires intellectual and imaginative work, not mere assertions that gendered meanings can be set aside. In the absence of that rethinking work, when we use inherited concepts we are liable to re-use their sedimented gendered meanings as well.

Feminist historians of philosophy have rarely looked at Schelling's work (but an exception is Assiter 2015). Yet for the last dozen years or so a major rebirth of interest in Schelling has been underway. English-language Schelling scholarship is rapidly growing, ${ }^{1}$ and an increasing number of theorists beyond Schelling scholars are returning to his ideas, a trend spearheaded by Zizek (e.g. 1996). Yet if we wish to bring Schelling's concepts forward into the present day, we need to examine their gendered meanings and ask how far we are willing to accept them today.

As indicated, here I undertake this examination in two stages. First, I look at the gendered contrast between natural forces in Schelling's First Outline. Second, I explain the rather different project of the Freiheitsschrift, in which ground and existence have gendered connotations continuous with those that inhibition and productivity had in the Outline. By reading the two texts together, then, we see a continuous strand in Schelling's thought. Discerning this strand requires that we spend some time reconstructing Schelling's ideas in these two texts, given their complexity and difficulty. Finally, I draw out the ambiguous implications of Schelling's claims as to the relative value of each gender, ${ }^{2}$ and I consider how all this bears on contemporary possibilities for re-appropriating Schelling's thought, with particular reference to Zizek. 


\section{Gender in the First Outline}

I begin by sketching the version of philosophy of nature that Schelling sets out in the First Outline. As with Schelling's preceding versions of this enterprise, it arose in part as a critical response to Kant's view that ordered experience and knowledge are only possible if the subject of experience applies categories, centrally including that of causality, to the materials of sensation. In turn, for Kant, that application is only possible through the subject's freedom or spontaneity, i.e. its power to perform actions independently of precipitating causes - and, notably, to apply categories because their use is warranted on a given occasion rather than merely because some causal force in my mind prompts me to do so. In short, knowledge as a normative phenomenon is possible only if knowers can act with spontaneity.

Yet, for Kant, the categories constrain us to experience nature-including ourselves insofar as we are part of nature - as a realm of objects whose interactions are causally determined in the manner theorized by Newtonian physics. How then can we exist and act as free subjects, and gain knowledge, within a natural universe in which all events are entirely causally determined? Part of Kant's answer is that ordered experience and knowledge require not that we actually are free but only that we can, indeed must, assume that we are free. In the Critique of Judgment, Kant further suggests that this requires us also to think of organisms, and of nature as an organized whole, as if they were 'purposive'-self-organizing in ways that prefigure the mind's capacity for ordering its own experience. Nevertheless, for Kant this is only a way of thinking about nature and organisms. We cannot know whether or not nature or organisms in themselves, independently of how we represent them, really are purposive (Kant [1790] 1987: §65-§67, 255-9). Our judgments of purposiveness are only 'regulative', not 'constitutive’' $(\$ 67,259)$.

Schelling, in contrast, argues that we as subjects of cognitive experience must really 
be free if we are to know the world, and that this freedom is only possible if nature really is spontaneous as well, independently of our thought about it: 'the purposiveness of natural products dwells in themselves, . . it is objective and real' (IPN 32/96). ${ }^{3}$ Nature as a whole must exhibit a level of freedom or spontaneity of its own, otherwise human subjects, situated amidst nature as they are, could never possess freedom either. Of course nature is not free in the same manner as human subjects, and neither are non-human organisms, but they must still have features that approximate to human freedom at a lower level, centrally including the power of self-organisation. The project of philosophy of nature, then, is to understand both the details and the overall manner in which freedom is prefigured within nature. 'To philosophise about nature means to lift it out of dead mechanism ... to animate it with freedom and to set it into its own free development' (FO 14/79). This is a question of describing how nature really, mind-independently is-for nature must really exhibit forms of proto-freedom if human beings are really to have freedom, as they must do to be capable of gaining knowledge as they are.

Scientists of Schelling's time, however, often understood natural beings in mechanistic terms, as composed of units of matter caught up in chains of efficient causation. Schelling therefore re-interprets natural forms and processes to reveal how, after all, they exhibit varying levels of self-organization. But Schelling does not simply devise an account of nature of his own which has no relation to scientific findings. On the contrary, he constructs his account of nature by drawing on the sciences of his time, but re-interpreting their findings in light of his overall metaphysics of free nature, or highlighting those particular findings that agree with his stance, identifying these as the most advanced or best scientific views.

Taking issue with Newtonian atomism in particular, Schelling takes it to be established by the better scientific theories of his time that matter is not fundamental but 
composed of prior attractive and repulsive forces:

Dynamic chemistry ... admits no original matter whatever-no matter, that is, from which everything else would have arisen by composition [as in Newtonian atomism]. On the contrary, since it considers all matter originally as a product of opposed forces (entgegengesetzter Kräfte), the greatest possible diversity of matter is still nothing else but a diversity in the relationship of these forces. (IPN 221/252)

Because these two forces structure matter, it prefigures subjectivity. The subject is always oriented both towards outer objects in the world, about which it tries to know, and back into itself inasmuch as whenever we know we are, necessarily, implicitly aware that we are doing so, self-referentially. The subject is attracted to know about objects in the world outside it and to repel these objects (as external to it) insofar as it returns reflexively into itself (IPN 176/214-5). The subject, then, is structured by a higher-level development of the same opposition between forces of attraction (or expansion) and repulsion (contraction) which we find in matter, right down to its lowest atomic level. Reciprocally, matter prefigures subjectivity. This is one instance of how Schelling thought that the sciences of his time could be interpreted as showing that nature anticipates free subjectivity.

In the Ideas, then, Schelling saw nature as organized by two fundamental forces: attraction, which is outward-oriented and expansive, and repulsion, which is inward-oriented and withdrawing. These forces organise matter, and from matter the whole gamut of natural phenomena is built up. In the First Outline, Schelling reconceives these two forces as those of production and inhibition.

Production has priority in the First Outline, since Schelling's overarching thesis here is that nature is originally productive. It originally consists of sheer, unlimited, productive activity (unendliche productive Tätigkeit). This productivity 'limits' (fixirt) itself to constitute the various particular products and processes that people the natural world. These products, 
Schelling insists, are not permanently fixed entities but only transitory resting points within nature's productivity — akin to eddies in a stream (FO 32/98). According to Schelling, the mistake of mechanistic science is to overlook the underlying productivity, 'the inner driving activity [Triebwerk]' (IO 196/32), which first makes possible the finite products, i.e. material units and their compositions, that this kind of science studies. Schelling, in contrast, aims to re-interpret the various finite natural products studied by the sciences as manifestations of nature's free productivity. In this way, once again, he discerns a kind of proto-freedom within nature - its productivity, which prefigures human spontaneity.

To explain how nature's productivity becomes confined in particular products, Schelling argues thus. Infinitely active as it is, nature's productivity would pass through an endless array of products infinitely quickly, destroying each product as quickly as it had been created, unless that productivity encountered some 'retarding' force (FO 187/266). Thus, the distinction between productivity and products must be explained by a prior duality of forces - a duality of productivity and another force opposing it. In Schelling's analogy, a river only forms eddies when its flow encounters resistance (IO 206/45-6). So, a force of inhibition—Hemmung—must oppose nature's productivity, so that particular products arise from the conflictual balance between productive and inhibiting forces. 'Each formation is itself only the ... appearance of a determinate proportion which nature achieves between opposed, mutually limiting actions' (FO 35/101).

Each natural 'product', then, is structured by a polarity: it reflects at once a given level of productivity and a given level of inhibition. For example, within the process whereby two elements interact chemically with one another, the point at which they react and exchange components embodies the moment when productive force prevails over the fixed 'products' in which it had been combined. But in that such reactions generate new 'products', say oxides, inhibiting force has once again come into play, binding productivity into a new 
finite shape.

For Schelling, a hierarchical series of natural forms arises within nature: every time productivity becomes bound into some specific range of entities, it bursts beyond this shape, but then becomes re-inhibited once more. Yet on each such occasion, productivity is spurred to display a higher level of freedom-cum-activity in its new effort to move beyond its preceding limitations, so that the products of nature become more and more organised and self-organising as we ascend the series. Chemical processes, for example, exhibit more activity and self-organisation than the efficient-causal interactions of bare units of matter. Living beings and their interactions exhibit still more activity and self-organisation.

The gendered connotations of these claims finally come into the open when, in his account of living beings - i.e. animals, including human beings, and plants — Schelling discusses sexual difference, Geschlechtsverschiedenheit. He understands the latter as follows. Nature overall can produce only when its two forces co-operate-when productivity acts, yet is hemmed in to some definite manifestation. In turn, if members of a living species are to reproduce, this is possible only if they partake in both the force of productivity and that of inhibition-producing something new that is nonetheless a determinate set of offspring. To the extent that both forces are prerequisites of reproduction, sexual difference is necessary, so that: 'Throughout the whole of [organic] nature absolute sexlessness is nowhere demonstrable' (FO 36/102). This makes it explicit, retrospectively, that productivity and inhibition have gendered connotations. If this were not so, then the fact that the two forces are necessary for organic reproduction would not entail that organic reproduction requires sexual difference.

However, it does not necessarily follow that the two forces should always be distributed asymmetrically between two distinct members of the species. Sometimes, in plants, a single individual can embody both forces. But in mammals, including human beings, 
the forces are divided between two individuals, so that these beings realise sexual difference properly. 'The separation into different sexes is just the [same] separation which we have furnished as the ground of inhibition in the productions of nature' (FO 39/105) - i.e., the female sex exists distinct from the male, just as inhibition must differ from, yet co-operate with, productivity. By implication, the female sex and inhibition go together, and so do the male sex and productivity.

The same assumption comes out when Schelling interprets sexual difference in terms of the difference between 'receptivity' and 'irritability' as John Brown understood them. On Brown's then-influential medical theory, disease arises from a mismatch between an individual's inherent level of 'irritability' and the level of stimulation impacting on them from the outer environment. Schelling interprets irritability as a manifestation of productive force and receptivity as a manifestation of inhibiting force. In his view, children are highly susceptible to stimulation — highly receptive_-but are low in irritability: i.e., in children inhibiting force prevails over the productive force. He adds:

If the organic power of resistance increases, the movements become more forceful, more energetic too-in equal proportion to the sinking sensibility.-Or, one might observe the difference of the sexes, or the climatic differences of peoples, or finally the increase of the forces directed outwardly in nature, which also happen in a certain (inverse) relation to sensibility. (FO 169/240-1)

Sexual difference, then, is illustrative of how sensibility (and inhibition) may prevail over irritability (and productivity), in happens in women as in children-while conversely, in more forceful and energetic people (i.e. men), irritability may reassert itself against sensibility.

In understanding productivity and inhibition in gendered terms, Schelling is building on a long philosophical history. Although Schelling's conception of these forces is all his own, he calls productivity nature's 'subjectivity' (IO 202/41) — it is that in virtue of which 
nature is active, creative, potent, and foreshadows human spontaneity. Conversely inhibition is cast in terms of withdrawal, passivity, and interiority. These connotations map closely onto the old association of men with activity and women with passivity, but also with the gender division of social roles that was crystallising in Schelling's time, with women confined to the 'interior' realm of the household whereas men 'go out' into the active domains of work and politics.

Here we should recall, too, the enormous influence on Schelling of his 1974 readings of Plato's cosmological dialogue the Timaeus. ${ }^{4}$ For Plato, the construction of the cosmos depends on the existence of the formless, primal, material space that he calls chora and explicitly describes in feminine terms, as the 'receptacle' and nurse of generation. For Plato, the cosmos as a structured realm arises from the interaction between form and primal matter. This view influenced Schelling's belief that two opposed yet co-operating forces are needed to generate the natural world. The place of the chora in Plato's Timaeus corresponds to that of the inhibiting, withdrawing, contracting force that Schelling identifies within nature - a force that carries over the feminine connotations that the chora had for Plato.

\section{Gender in the Freiheitsschrift}

Schelling's philosophical standpoint in the Freiheitsschrift differs markedly from that of the Outline, but this does not represent a sharp break in his thought. Rather, Schelling's previous positions generated particular problems, and his efforts to solve these led him to the significantly modified views that we find expressed in the Freiheitsschrift.

To elaborate: When he was developing his philosophy of nature, Schelling simultaneously also worked on his 'transcendental philosophy': his account of subjectivity and its forms, which realise at increasingly advanced levels the power of self-determination already prefigured in nature. However, Schelling was not convinced that he had adequately 
understood how nature and subjectivity belong together as two modes of a single ultimate reality. Thus, in 1801 he adumbrated the 'identity philosophy', focusing directly on the absolute as a unity and how its unity grounds these different manifestations in nature and mind. This stance generated a host of questions about how to understand the relation between the absolute one and the many finite differences.

These, along with several other intersecting questions, led to the revised set of formulations set out in the Freiheitsschrift. One of these further questions concerns the character of human freedom, which, Schelling became increasingly insistent, consists in the capacity to choose between good and evil as two equally possible options. That is, evil is not merely a lack of goodness, and more specifically it is not merely the result of a subject's failure to exercise the freedom to act from reason, i.e. from the categorical imperative- the view of evil that appeared to follow from Kant's ethics (Kant's own efforts to address this problem notwithstanding). In that case the subject would not choose evil but would only exercise choice at all in acting from the good—which makes our responsibility for evil puzzling.

Instead, then, Schelling insists, evil is something we can positively choose to commit, just as alternatively we may choose the good (PUF 23/25). Further, evil must be understood actually to tempt or solicit us (41/46). For this to be possible there must be forces within each of us that prompt us to commit evil when the occasion arises, even though we also have inner forces motivating us to do good, which we can choose to prioritise over the evil ones. In sum, doing justice to human freedom requires a picture of human beings as torn between competing impulses, never exempt from the attractions of evil.

Given that Schelling already took the view that finite things unfold from and manifest the absolute one, however, this picture of human agency has ramifications for how the absolute must be thought. The absolute must contain within itself something akin to the 
opposing forces within human agents, so that those forces in their human manifestation are explained from the absolute. Thus, the absolute must have within it forces prefiguring those of evil and good as the latter exist in human beings. Furthermore, to prefigure the human freedom to choose between these forces and to prioritise the good, the absolute must have a personal character, anticipating that of the choosing human agent, and anticipating the human capacity to do good. So, more robustly than ever before, Schelling equates the absolute with the personal, Christian God.

But since 'everything positive [i.e. definitely existing] in creatures comes from God', and since it is also the case that if 'there is something positive [i.e. a definite force] in evil, then this positive comes also from God', Schelling's claims seem to entail that evil is in God - that God harbours tendencies to evil, even if he always sets his face against them (PUF 23/26). Not surprisingly, since this would be a very heterodox claim, Schelling argues otherwise. Nonetheless there must be something in God that provides the ground of the evil tendencies found in human agents. To say this without implying or concluding that God contains evil, Schelling argues that this 'something' is that in God which is contrary to his own nature, which he constantly negates, and indeed through the negation of which he becomes himself as the good, personal God. At the same time, Schelling maintains that this 'something' is what God negates within himself - it cannot fall outside of God or he would not be the absolute. This 'something' is, then, ambiguously both in but not of God: God contains an internal opposition. This 'something' is God's 'ground' of possibility-that which is the condition of his possibility insofar as he must negate it to be himself qua good. So whereas God in his existence is good and rational, and creates the world in accordance with these traits, his ground by contrast is a more primeval force of generation, which both prefigures (makes possible) God's creativity and is opposed to that creativity in being nonrational and chaotic. The ground, therefore, is the brute upsurgence by which existence comes 
forth, a primordial movement through which it becomes possible for there to be anything at all (PUF 27/30).

Schelling ties this distinction back to his ethical concerns as follows. Evil is not in God, because he intrinsically negates his ground; at the same time, he is inseparably united with that ground, without which he cannot exist, albeit that this is an antagonistic and not a harmonious unity. In the finite, created natural world within which human beings are situated, what is united in God becomes unfolded into all its differentiae, all existing outside one another. Hence the potential for evil that was in God's ground comes to exist separately from his existent goodness, as a separate force for evil to which human agents are subject along with the impulse to the good (PUF 33/36). The capacity for choice, too, becomes a distinct faculty in human agents: the faculty to prioritise good or evil. God's internally complex character, then, makes human evil possible without his directly being evil himselfSchelling's solution to the age-old problem of evil, which is another of the various problems motivating him to the stance embraced in the Freiheitsschrift.

But what qualifies certain promptings within human beings as evil? Informed by Kant, Schelling holds that to act with a good will is to do what is rational and, being rational, obtains as a universal law-i.e. to do something that any agent faced with a like situation has rational grounds to do, so that if I have a reason to $X$ then so does anyone else facing the same options. Conversely, then, to act with an evil will is to turn away from what reason legislates and pursue the satisfaction of impulses that I have just as the particular individual I am, constituted just as I am, in fact. That is, evil is linked with particular individuality and with what just is, sheer contingency_-'blind will' or 'self-will' (blinder Wille, Eigenwille PUF 32/35). On the divine plane, what prefigures this in God's ground is the fact that it just is, as brute emergence from non-being into being; and that what emerges is just whatever it is, in its inexplicable particularity. 
Thus the ground is non- or irrational, i.e. chaotic - it defies our understanding, for there is no reason why it is as it is. The ground exceeds our understanding: 'This is the incomprehensible [unergreifliche] basis of the reality in things, the indivisible remainder, that which with even the greatest exertion cannot be resolved into the understanding but remains eternally in the ground' (29/32). And so, as indeed in this passage, Schelling describes the ground mainly using metaphorical, poetic language, which is suited to evoke and grope towards that which no concepts can cover exhaustively. The language of darkness and light, for instance, is pervasive.

At this point, let me note one final concern that prompted Schelling to develop these seemingly esoteric views. Schelling became increasingly convinced that the fact of something's existing can never be guaranteed just by its concept; even if it is in something's concept (as with God) to exist, its actual existence is still something over and above that. Something's concept may tell us that if it exists, then it does so with necessity, but not whether it exists at all —whether the concept is instantiated. Thus there is a distinction between the sheer facticity of what is and the domain of concepts, and this is encapsulated in the distinction between God's ground and his existence.

The gendered connotations of Schelling's concepts are fully explicit. He equates God's ground with the female and, specifically, the maternal body. The ground is persistently linked with birth: 'it is the yearning [Sehnsucht] [that] the eternal One feels to give birth to itself [sich selbst zu gebären] ... the yearning wants to give birth to [gebären] God' (28/31). And 'All birth is birth from darkness into light': seeds come to fruition in the darkness of the earth; likewise, the human being is 'formed in the maternal body [Mutterleibe]; and only from the darkness of that which is without understanding (from feeling, yearning, the sovereign mother of knowledge) grow luminous thoughts' (29/32-3). The ground is identified as female, then, along a whole series of conceptual contrasts with the existing God, who 
counts as male because he negates the female ground, in line with Judaeo-Christian tradition. ${ }^{5}$ On the one hand, then, we have the ground - what is chaotic and non-rational, a movement of brute emergence into existence, marked by a desire or longing for full existence, which feels, yet lacks and exceeds understanding. On the other hand, we have God in his full personhood - who is rational, who creates in accordance with reason and the good, who fully exists, and who guarantees the intelligibility of things in general.

As in the Outline, in the Freiheitsschrift two powers are again responsible for the generation of the cosmos. But in the Outline these were described as forces, in quasiscientific language. In the Freiheitsschrift the two powers are instead aspects of God-the language is religious. What was pure productivity in the Outline has been reconceived as God, as creative agent; what was inhibition is now God's ground, which turns inward upon itself - away from our efforts to comprehend it, and away from God's existence proper. As with inhibition previously, the ground recedes and hides in darkness, whereas God as creative existent comes out into the light.

The distinction between quasi-scientific and theological vocabularies is not sharp as it might appear, though. Just as Schelling was always drawn to the Spinozist view of God-ornature, in the Freiheitsschrift he identifies God's ground with nature, so that the ambivalent unity of God and his ground is equally that of God and nature. The nature that is the ground is not created nature (natura naturata), the product of God's creation, but creative nature (natura naturans). What it contributes to created nature is the latter's all-pervasive aspect of sheer contingency and brute emergence just as it is, in contrast to its intelligibility, which descends from God as creative subject.

As this indicates, although the ground is a descendant of the earlier notion of inhibition, there are also palpable shifts in how the ground is understood compared to inhibition. Inhibition was necessary for the production of natural forms, but inhibition was 
not itself directly productive, but rather contributed to production by retarding and limiting pure productive force. This still meant that inhibition was a force, exercising limiting power with respect to productivity; but inhibition was not directly a productive force. In the Freiheitsschrift, though, the ground is generative, directly so; its generativity makes it possible for God to exercise creative agency, which he does in realising more fully the generative movement into existence in which the ground already consisted. In this way, God's creativity depends more deeply on the ground than productivity depended on inhibition. Productivity could operate without inhibition in principle, but it needed inhibition to produce anything determinate. In contrast, God's creativity can only arise and operate at all as the realisation of the generative power already latent in the ground. In this sense, we might think that the female principle has gained a new level of power and importance relative to its male counterpart. This gain partly reflects Schelling's increasingly conviction that considerations of reason are secondary to facts of pure existence, which, given his broad associations male-reason/female-existence, shifts the 'female' side of the equation into prime position. Yet we may well still be dissatisfied with Schelling's assumptions about gender, for a number of reasons, to which I now turn.

\section{Gendered values in Schelling's thought and its contemporary uses}

There are several problems with Schelling's assumptions about gender. First, there is his equation of the female with the maternal in the Freiheitsschrift. Second, there is the association of the female with the non-rational and of the male with the rational, as well as the preservation of the traditional Judeo-Christian belief in a male God. Third, there is the fact that the female ground, although not itself evil, is the condition of possibility of evil, which is an active, tempting force within human agents. Although the alignment is complicated and nuanced, the fact remains that the female is broadly aligned with evil here, 
whereas the male is broadly aligned with good through the connections between God, the good and reason. Once again, these alignments show the influence of Plato's Timaeus:

Now it appears that the solicitation to evil itself can only come from an evil fundamental being [Grundwesen], and the assumption that there is such a being seems nonetheless unavoidable; it also appears that that interpretation of Platonic matter is completely correct according to which matter is originally a kind of being that resists God and that for that reason is an evil being in itself. (41/46)

Schelling goes on to tell us that he does not entirely agree, for he neither regards matter (nor the ground) as a being entirely outside God nor regards the ground as in itself actually evil; nonetheless, as he is indicating in the above quotation, he is informed by Plato, even as he qualifies Plato's position.

Should anyone be tempted to dismiss all this as mere metaphor from which Schelling's key concepts can be extracted, we should remember that metaphor is integral to Schelling's description of the ground insofar as it defies conceptual understanding. Without metaphor and imagination we would have no notion of the ground at all. And amongst these metaphors, those of birth and the maternal body are central.

By this point, it may seem as if Schelling has a straightforwardly hierarchical conception of the two sexes. The female potential for and proclivity towards evil remain just that - mere potential and unrealised proclivity — as long as they are contained within structures whereby God and the human agent negate them. That is: the female carries the seeds of evil, but as long as it is subordinated underneath the male the danger can be averted. However, Schelling is actually ambiguous on the value of the two sexes. His thought does have hierarchical implications yet, on the other hand, there is the thought that the female ground is necessarily prior to male existence, and that the most primordial kind of production is female generation as distinct from male creation. For this reason Assiter (2015) views 
Schelling's Freiheitsschrift positively, as a recovery of the forgotten power of female birthgiving. Moreover, whereas in the Outline the female was not itself productive, in the Freiheitsschrift it is. And although the female is aligned with unreason and with what just emerges, by the same token brute facticity is given priority to reason and understanding: something must first exist before it can conform or fail to conform to concepts. To be sure, Schelling does not challenge the traditional set of conceptual oppositions with which he is working - those of female-irrational-nature-evil versus male-reason-subjectivity-good. But to some extent he reverses the hierarchy in which these were traditionally placed, i.e. where the male had been ranked 'above' the female. Schelling goes some way towards reversing that ranking, by affirming that the 'female' set of elements has ontological priority.

To complicate matters further, though, Schelling regularly draws back from giving this priority to the female side of the equation. For instance, having just stated that 'God has in himself an inner ground of his existence that in this respect precedes him in existence' [my emphasis], he then adds 'but, precisely in this way, God is again the prius of the ground in so far as the ground, even as such, could not exist if God did not exist actu' (PUF 28/31). That is, the ground is that in God without which he could not exist, a ground which, therefore, would not be possible if God did not exist, for it is part of him, albeit part of him that turns away from him and against which he sets himself. Accordingly, Schelling states that God alone is 'begotten from himself' (er allein ist von sich selbst;29/32).

On the positive side, then, Schelling consistently recognises female elements in the cosmos. In the Outline, he maintains that a female principle is necessary alongside the male one in the generation of the world. And in the Freiheitsschrift he goes further, albeit with some qualifications, in giving central importance to the maternal body and to the female principle of birth-giving. Indeed, the Freiheitsschrift tends towards the thought that the female and maternal principle is the most fundamental one metaphysically. On the negative 
side, Schelling does not challenge the gendered oppositions with which he works; at most he reverses the respective values assigned to the male and female sides of these oppositions. At other times he falls back towards seeing the female as needing subordination under the male principle if anarchy is to be averted. Plausibly, these drawbacks of his way of thinking are connected. If one tries to revalue the associated terms female-unreason-body-matter-evil (etc.) but does not challenge their association or their opposition to the series male-reasonmind-good (etc.), then it will be difficult to revalue the female terms consistently in the first place. For their sedimented meanings include that of being inferior to their male counterparts - meanings, therefore, that will inevitably tend to seep back into one's attempted more positive picture.

To illustrate how these issues bear on contemporary readings of Schelling, let me briefly turn to Zizek. One of the ways he uses the core concepts of Schelling's Freiheitsschrift is to transpose them into the political domain, for example in his essay 'A Leftist Plea for "Eurocentrism", (Zizek 1998). Schelling is not overtly mentioned here, beyond one use of the phrase 'the indivisible remainder' and Zizek's references to his own earlier book on Schelling (Zizek 1996). But implicitly the Freiheitsschrift is pervasive. Zizek argues that politics proper requires a traumatic break from the established horizon of meaning, order and intelligibility, a break in which a hitherto excluded or subordinated group asserts that it is the universal - the people, the demos, the republic, the nation, the whole society, etc. (989). That is, we have here a group that is external to and opposed to the existing order and yet is internally necessary to the workings of that order-which thus occupies the position of the ground, the 'non-part', vis-à-vis the existing order, where the latter is equivalent to God's realm of intelligible order. The political moment is one in which this excluded group, excessive with respect to the order of the time, erupts and re-defines what counts as intelligibility and order. But this transformative agency does not reject 
intelligibility or order; it instead re-shapes the latter, by declaring itself to be the universal. Thus, Zizek is adamant that genuine politics must concern the universal, and so he sets himself against 'postmodern multi-culturalism' and 'identity politics' which affirm the particularity of different groups — including women — and so which, by his lights, are symptomatic of the depoliticisation of the present time (1006-7).

We can see here that Zizek takes up Schelling's accordance of ontological priority to the ground: the ground, a.k.a. the excluded group, must burst forth for politics proper to become possible. But, and again in a way faithful to Schelling's framework, Zizek holds that the ground on its own is not enough to yield politics. Politics arises only once where the irruptive potential of the ground is taken up into existence, in the form of a claim to universality. This taking-up leaves a remainder-i.e. there is a fundamental antagonism between the particularity of the group and its claim to universality (or, between God's ground and existence)—but that antagonistic unity is nonetheless key to politics.

The gendered connotations of Schelling's ground/existence contrast feed through into Zizek's dismissal of 'multi-culturalism' and feminism considered as a form of identity politics. Reflecting the original female connotation of the ground, Zizek associates particularity on its own, i.e. a-political particularity, with the 'multi-cultural' project and with the affirmation of feminine values and women's particular interests and needs. On the other hand, and reflecting the original male connotation of God as creative existence, the affirmation of a universal community is celebrated for being 'properly political'. To be sure, it is properly political only when it incorporates a 'female' dimension, in that an excluded particular proclaims itself to be universal. But, at the same time, that 'female' dimension only becomes political once it is incorporated into a structure that includes 'male' universality. In sum, Zizek adheres to an age-old set of associations female-particular-private/male-universal- 
political. Old as these associations are, they re-appear in Zizek's framework by virtue of his taking up the already-gendered ideas of God and his ground from Schelling's Freiheitsschrift.

To conclude, I have tried to show that gendered meanings are woven integrally into Schelling's thought. If we take up Schelling's ideas, even by creatively transposing them from metaphysical to political registers as Zizek does, then we are liable to take up their gendered meanings at the same time. Some might be unconcerned by this, but I believe that we need to be critical of these sedimented meanings. A first step towards re-thinking them is to study how they function in Schelling's thought. Doing this can also help us to make sense of Schelling's ideas more generally, insofar as gendered connotations are thoroughly woven into these ideas. In this case, I hope to have illuminated continuities between Schelling's philosophy of nature and his Freiheitsschrift, continuities that become visible once we attend to gender. Both for critical feminist purposes and for purposes of exegesis and understanding, examination of the gendered aspects of Schelling's thinking ought to form a vital part of contemporary efforts to reconstruct and appropriate his philosophy.

\section{References}

(NB. Bibliographic details of repeatedly cited works by Schelling are listed in note 3.) Assiter, Alison (2015) Kierkegaard, Eve and Metaphors of Birth. Lanham, MD: Rowman \& Littlefield.

Baum, Manfred (2000) The Beginnings of Schelling's Philosophy of Nature, in Sally Sedgwick (ed.), The Reception of Kant's Critical Philosophy. Cambridge: Cambridge University Press.

Daly, Mary [1973] (1985) Beyond God the Father. Boston: Beacon Press.

Gabriel, Markus (2013) Transcendental Ontology: Essays in German Idealism. London: Bloomsbury. 
Kant, Immanuel [1790] (1987), Critique of Judgment, trans. Werner S. Pluhar. Indianapolis: Hackett.

Lloyd, Genevieve (1984) The Man of Reason: 'Male' and 'Female' in Western Philosophy. London: Routledge.

Norman, Judith, and Alistair Welchman, eds. (2004) The New Schelling. London: Continuum.

Ostaric, Lara, ed. (2014) Interpreting Schelling: Critical Essays. Cambridge, UK: Cambridge University Press.

Sallis, John (1999) Secluded Nature: The Point of Schelling's Reinscription of the 'Timaeus', in Pli: The Warwick Journal of Philosophy 8: 71-85.

Schelling, F. W. J. [1794] (1994) 'Timaeus’ [1794], ed. Hartmut Buchner. Stuttgart-Bad Canstatt: Frommann-Holzboog.

Wirth, Jason M., (2003) The Conspiracy of Life: Meditations on Schelling and His Time. Albany, NY: SUNY Press.

—., ed. (2004) Schelling Now: Contemporary Readings. Bloomington, IN: Indiana University Press.

Zizek, Slavoj (1996) The Indivisible Remainder: An Essay on Schelling and Related Matters. London: Verso. (1998) A Leftist Plea for 'Eurocentrism'. Critical Inquiry 24 (4): 988-1009.

\footnotetext{
${ }^{1}$ See, amongst others, Gabriel 2013, Norman and Welchman 2004, Ostaric 2014, Wirth 2003, 2004.

${ }^{2}$ I use 'gender' to refer to meanings assigned to the sexed body, rather than distinguishing sex from gender sharply. Hence I speak of Schelling's conceptions of the male and female,
} 
not of the masculine and feminine.

${ }^{3}$ Abbreviations for Schelling's works (translations are occasionally amended without special notice):

FO = First Outline of a System of Philosophy of Nature, trans. Keith R. Petersen (Albany, NY: SUNY Press, 2004)/Erster Entwurf eines Systems der Naturphilosophie, in Werke: Historisch-kritische Ausgabe Reihe 1, ed. Wilhelm G. Jacobs and Paul Ziche (Stuttgart: Frommann-Holzboog, 2001), vol. 7.

IO = Introduction to the Outline of a System of the Philosophy of Nature, or, On the Concept of a Speculative Physics and the Internal Organization of a System of this Science. In First Outline, trans. Petersen (2004)/“Einleitung du zem Entwurf eines Systems der Naturphilosophie,“ in Schriften(1799-1800), Werke: Historisch-kritische Ausgabe Reihe 1, ed. Manfred Durner and Wilhelm G. Jacobs (Stuttgart: Frommann-Holzboog, 2004), vol. 8 .

IPN = Ideas for a Philosophy of Nature, trans. Errol E. Harris and Peter Heath (Cambridge:

Cambridge University Press, 1988)/Ideen zu einer Philosophie der Natur, ed.

Manfred Durner, Werke: Historisch-kritische Ausgabe Reihe 1 (Stuttgart: FrommannHolzboog, 1994), vol. 5.

PUF $=$ Philosophical Investigations into the Essence of Human Freedom, trans. Jeff Lowe and Johannes Schmidt (Albany, NY: SUNY Press, 2006)/Über das Wesen der menschlichen Freiheit, ed. Thomas Buchheim (Hamburg: Meiner, 1997).

${ }^{4}$ See Schelling [1794] 1994, and, for commentary, Baum 2000, Sallis 1999.

${ }^{5}$ It may be worth recalling here Mary Daly's remark summing up —if rather simplisticallythe patriarchal character of Judeo-Christianity: 'If God is male, then the male is God' [1973] (1985: 19). 